\title{
Lessing e as vespas
}

Anabela Mendes

Anabela Mendes

é docente da Universidade de Lisboa.

\section{DRAMATURGIA \\ DE HAMBURGO \\ Selecção antológica}

Gotthold Ephraim Lessing

SERVTCO DI HDUCACGOEHOLAS FUNDACX̃O CALOUSTE GULBENKIAN

Em Maio de 1775, Lessing abandona temporariamente as funções de bibliotecário em Wolfenbüttel, que aceitara desempenhar desde finais de 1769 e ao serviço do duque Karl von Braunschweig, para acompanhar como "cicerone", numa viagem literária e espiritual pela Itália, o filho do seu senhor, o príncipe Julius Maximilian Leopold von Braunschweig-Lüneburg, também sobrinho de Frederico II da Prússia.

Esta sua viagem, não explicitamente desejada, transformou-se em termos gerais num processo de representação e exercício diplomático a que o autor procurou corresponder com toda a correcção e interesse, consciente de que a missão de cicerone de que fora incumbido estaria sempre limitada pelo desconhecimento objectivo da realidade territorial e do povo visitado, pudessem embora ser úteis todas as suas leituras, observações de modelos e reflexões sobre a natureza estética e cultural de obras artísticas, baseadas na sua experiência como erudito e homem de teatro. Pense-se, por exemplo, no Laocoonte, de Hagesandro, Atenodoro e Polidoro, exposto no Museu do Vaticano, e que Lessing só viria a contemplar no original durante esta viagem, mas que conhecia e muito apreciava, através de cópias

\author{
Gotthold Ephraim Lessing, Dramaturgia \\ de Hamburgo: Selecção antológica \\ $[1767,1769]$, traduçã̉o, introdução e notas \\ de Manuela Nunes, Lisboa, Fundação \\ Calouste Gulbenkian, 2005, 207 pp.
}

em gesso, o que, aliás, não o impediu de tomar essa obra de arte grega como ponto de partida nuclear para a sua dissertação estética Laocoonte ou sobre as fronteiras da pintura e da poesia, escrita em 1766.

Se o peso da incumbência italiana priva Lessing de gerir o seu tempo com liberdade e o afasta de objectivos mais propicios aos seus interesses pessoais (carta à noiva Eva König, de 8 de Maio de 1775), essa tarefa acaba por activar no dramaturgo, ensaista e médico Lessing qualidades que ele treina desde os tempos de estudante em Leipzig e que dão ênfase à sua formação científica e experimental.

Roma apresenta-se como o lugar adequado para pôr à prova o pensamento indutivo. Aí irá funcionar o laboratório das aferições: comparar exemplares de facto com as respectivas descrições, há muito lidas e anotadas, de obras de arte antiga e renascentista e respectivas representações; este percurso apresenta-se como uma transposição metodológica lessinguiana praticada em larga escala na sua Dramaturgia de Hamburgo. Em Roma exercita Lessing os seus conhecimentos teórico-estéticos na presença das obras de arte que aprecia não para ensinar mas para aprender.

0 que de mais interessante existe, do meu ponto de vista, na obra Dramaturgia de Hamburgo, que Lessing foi escrevendo entre 1767 e 1769, diz respeito ao modo como o seu pensamento se estrutura enquanto linguagem, deixando que os seus leitores partilhem com ele os avanços e recuos de processos mais do que resultados no campo da elaboração de textos dramáticos, na escolha de reportórios, na construção de espectáculos, na análise da reacção e formação de públicos. 0 sentido histórico desta obra dilui-se perante o enorme manancial de propostas com que somos confrontados.

$\mathrm{Na}$ verdade este conjunto de 104 secções, ao longo de cerca de 650 páginas que constituem esta obra tem hoje um interesse relativo para o leitor contemporâneo, mas é nela que aprendemos a perceber como Lessing se confronta com a tradição greco-latina, em particular com Aristóteles, pondo em causa de forma científica, por exemplo, o uso de termos próprios da teoria da Tragédia como terror - temor, piedade - compaixão, insurgindo-se contra más traduções de seus contemporâneos e contra o uso e abuso ortodoxo de terminologia poética esvaziada de sentido. 
Francesco Queirolo,

0 desengano, Capela de São Severo, Nápoles, cc. 1752.

Lessing com 6 anos

(à direita) como

o irmão Teófilo,

óleo de Gottlieb Habekorn,

Berlim, Arquivo para a

Arte e a História, s.d.
Essa qualidade, que o dramaturgo desenvolve, de registar as características de cada representação, de estabelecer comparações entre representações, de alargar o horizonte das mesmas com materiais e ideias que desde a juventude transportava na sua memória de autor, fazedor e amante de teatro, em directo contacto com o espaço cénico e com os seus agentes, distingue Lessing da maior parte dos seus contemporâneos.

Consciente de que a sua visão progressista e empenhada, face ao teatro alemão como instituição, não colhera em Hamburgo qualquer aplauso da parte de financiadores da rica burguesia hanseática, Lessing retirase para o espaço de uma biblioteca estadual até ao fim dos seus dias. Ai escreve, em viuvez sofrida e profunda solidão, a sua obra mais complexa e de extrema actualidade Nathan, o sábio.

Desde 2005 que podemos ler em português muito correcto uma selecção antológica da Dramaturgia de Hamburgo de Gotthold Ephraim Lessing, da autoria de Manuela Nunes, publicada pela Fundação Calouste Gulbenkian. A tradutora escreve com critério uma introdução que enquadra bem, do ponto de vista teatrológico, o autor e a sua obra na época, criando-se aqui e acolá algumas comparações com o teatro português dos séculos XVIII e XIX. Esta tradução tem o mérito de vir anotada, o que facilita ao leitor menos inserido no contexto um percurso informativo mais seguro.

Opções pontuais como, por exemplo, a da palavra "fascículo" para Stücke, não me parece estar bem defendida. A minha sugestão seria "secção", que melhor se aproxima da formulação científica que Lessing utilizava também em outras obras de natureza ensaística. Recordo, a propósito, a tradução de João Barrento, de textos da Dramaturgia de Hamburgo em obra publicada em 1989 (João Barrento, Literatura alemã textos e contextos (17001900) - O século XVIII, vol. 1, Lisboa, Editorial Presença, pp. 109-114)
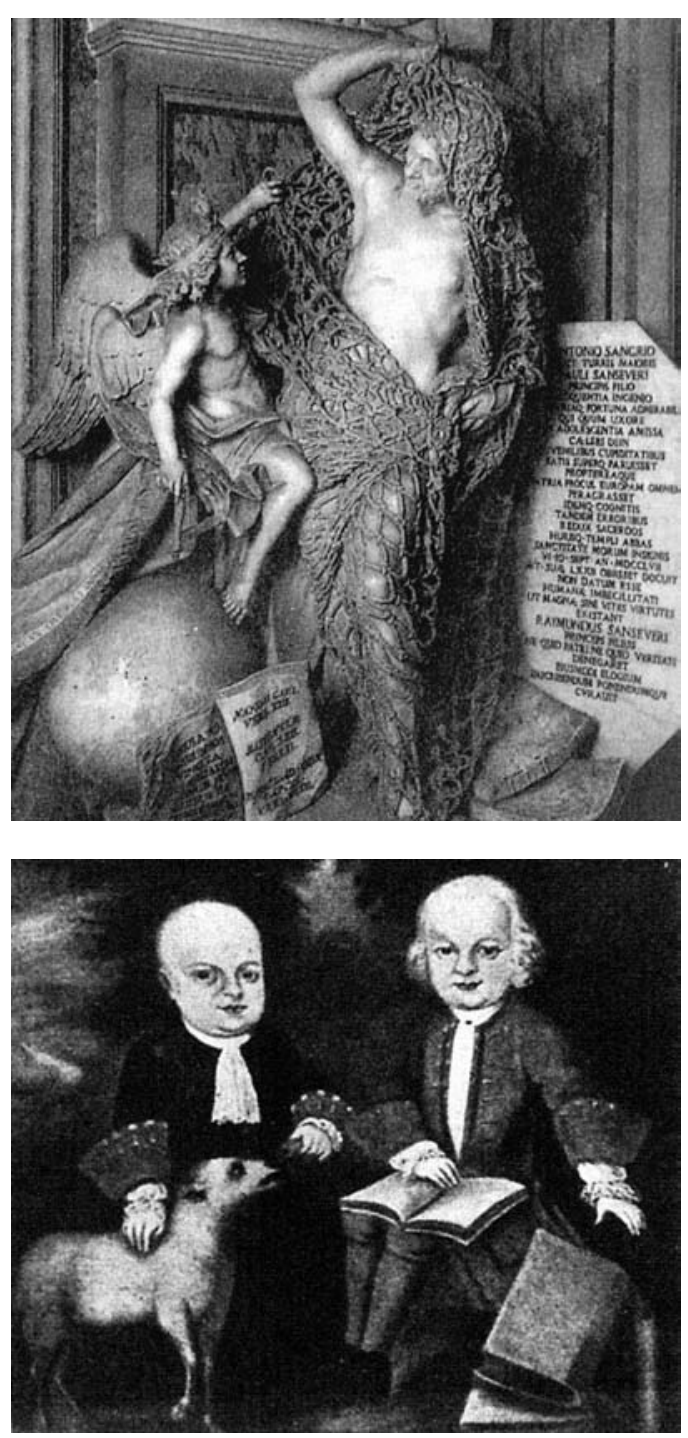

Este gesto intelectual de trazer a público uma obra teórico-prática de Lessing em língua portuguesa merece o nosso regozijo. Quem sabe se um dia não haverá vontade institucional de traduzir a Dramaturgia de Hamburgo na sua totalidade? E por que não obras dramáticas de Lessing? Quando alguns clássicos voltarem a espreitar em época propícia por entre as portas de uma cultura europeia aberta e esclarecida, talvez se extinga o zunir das vespas, que o humor de Aristófanes tão bem tratou e que Lessing tanto apreciava. 